Устич C.I.,

доктор соиіологічних наук, професор, завідувач кафедри міжнародних студій та суспільних комунікацій ДВНЗ «Ужгородський національний університет», Надзвичайний і Повноважний Посол (м. Ужгород, Украӥна)

\title{
СОЦІОЛОГІЧНА РЕФЛЕКСІЯ В СИСТЕМІ ІНФОРМАЦИЙНОГО СЕРВІСУ ТРАНСКОРДОННОГО СПІВРОБІТНИЦТВА
}

У статті аналізуються проблеми соиіологічного відображення сучасних транскордонних проиесів, зокрема на новому Східному кордоні Європейського Союзу. Обгрунтовується поняття «система інформаиійного сервісу транскордонного співробітництва», досліджується місие та функиії конкретно-сочіологічного знання в цій системі.

Ключові слова: сочіологічна рефлексія, транскордонні процеси, система інформаиійного сервісу транскордонного співробітництвв.

The article analyzes the problems of sociological reflection of modern transborder processes, in particular on the new Eastern border of the European Union. The concept of "system of information service of cross-border cooperation" is substantiated, the place and functions of concrete sociological knowledge in this system are investigated.

Keywords: sociological reflection, cross-border processes, system of information service of cross-border cooperation.

Із безпосереднім виходом Європейського Союзу до кордону із Україною у Свропи з'явився справжній, об'єктивно зумовлений стратегічний інтерес у безконфліктному та поступальному розвитку свого східного сусіда в цілому та його контактних прикордонних регіонів зокрема. Завдання ж України зараз полягає в тому, щоб використати цей інтерес сповна.

Безперечно, розширення Європейського Союзу на Схід створило також чимало серйозних ускладнень та дискомфортних явищ, найперше в комунікаційному просторі. Запровадження жорсткого візового режиму значно ускладнило комунікацію людей, зокрема тих, хто має родинні зв'язки, а також тих, хто об'єднаний національною, культурною, конфесійною ідентичністю. Загострилися проблеми економічної активності, безробіття серед населення депресивних прикордонних регіонів. Криміногенні явища, зокрема нелегальна міграція та контрабанда товарів, не зникли, вони набувають нових, часто більш витончених форм.

Все це вимагає адекватної реакції суб'єктів управління по обидві сторони нового Східного кордону Європейського Союзу. Не можна не 
помітити, що органи управління на різних рівнях (від Свропейської Комісії та урядів сусідніх країн до місцевої влади) докладають зусиль для вирішення непростих проблем прикордоння, що, безперечно, дає певний позитивний результат.

Але викликає подив те, як мало при цьому приділяється уваги підтриманню «зворотного зв'язку» із основними суб'єктами транскордонних процесів - жителями прикордонних регіонів, тими, кого останні геополітичні зміни торкнулися в першу чергу, i більш всього - вивченню їх думок, настроїв, оцінок.

Відсутність «альтернативної» стосовно офіційної інформації породжує ланцюжок взаємопов'язаних проблем.

Органи управління часто приймають ті чи інші рішення, не маючи повної, всебічної та достовірної інформації. При цьому вони нерідко спираються на односторонні та бюрократичні оцінки тих чи інших відомств. В результаті такі рішення виявляються малоефективними i, по суті, не розв'язують проблеми, а імітують їх розв'язання. За прикладами далеко ходити не треба. Ми не раз були свідками того, як багатообіцяючі заяви високих дипломатичних представників Європейського Союзу щодо лібералізації візового режиму із східними партнерами згодом по суті дезавуюються керівниками відомств ЄC, що відповідають за безпеку кордонів. Чи взяти проблему корупції, яка, незважаючи на демонстровані зусилля по iï подоланню (до прикладу, запровадження так званої «гарячої лінії» для звернень громадян), як добре відомо, процвітає на кордоні та має місце у візовому обслуговуванні консульствами.

В свою чергу, неефективні рішення, що не вирішують проблеми по суті та послідовно, викликають їх несприйняття, чи навіть активне відторгнення населенням. Більш того, трапляється, вони провокують нові ускладнення (прикладом можуть слугувати конфліктні ситуації, що час від часу виникають на кордоні між прикордонним персоналом та громадянами).

Тому встановлення (налагодження) «зворотного зв'язку», отримання «альтернативної» інформації про функціонування кордону є вкрай важливою умовою оптимізації транскордонного співробітництва. Вирішити ж ияю головну проблему можна тільки иляхом використання спеціальних методів вивчення громадської думки, забезпечення адекватної сочүіологічної рефлексії транскордонних проиесів.

Метою цієї статті $\epsilon$ аналіз проблем конкретно-соціологічного відображення транскордонної реальності в Центрально-Східній Європі та 3'ясування місця соціологічної складової в системі інформаційного забезпечення сучасного транскордонного співробітництва.

Поняття «сочіологічна рефлексія транскордонних прочесів» означає як аналіз формування та розвитку самого конкретно-соціологічного знання про явище «транскордонного», так $і$ дослідження прийомів та методів, щуо 
використовуються в конкретно-соціологічному пізнанні и̧ього важливого феномену соиіальної дійсності.

У якому ж стані знаходиться нині соціологічна рефлексія транскордонних процесів?

Найперше розглянемо діяльність у цій царині Європейського Союзу. Відомо, що вивченням суспільних настроїв у цьому об'єднанні держав займається уповноважена структура, що зветься Євробарометром. Свробарометр (англ. Eurobarometr) - міжнародний проект регулярних опитувань громадської думки, що здійснюється під егідою Європейської Комісії [1]. Одним із основних партнерів Свробарометру є група Taylor Nelson Sofres (TNS) - світовий лідер в галузі маркетингових досліджень «на замовлення» [2].

Аналіз опублікованих Свробарометром упродовж чотирьох десятиліть i особливо в останні роки (після розширення Свропейського Союзу на Схід) матеріалів показує, що, на жаль, серед них немає спеціальних досліджень проблем прикордоння, тим більше таких, що присвячені транскордонним процесам на новому Східному кордоні Свропейського Союзу. Тільки в одному із досліджень, проведеному в 2006 році і присвяченому вивченню наслідків розширення $\mathrm{CC}$, в дотичній формі порушуються і деякі питання функціонування кордонів та сучасного розвитку прикордонних регіонів.

Це досить дивно, адже поза належною увагою опинився цілий пласт гострих проблем, що викликають постійні дискусії у самому Свропейському Союзі (перш за все це проблеми міграції та безпеки). Для порівняння, інше відомство Свропейського Союзу, що опікується статистикою - Свростат - в останні роки дуже активно і цілеспрямовано займається розробкою проблематики кількісної оцінки транскордонних процесів («транскордонною статистикою»), найперше на новому Східному кордоні ЄC [3]. Цим проблемам, зокрема, була присвячена загальноєвропейська конференція керівників статистичних відомств та науковців, що відбулася в Кракові в 2011 році. Безумовними європейськими лідерами розробки проблем транскордонної статистики є польські вчені і практики на чолі із професором Йозефом Оленським, який тривалий час очолював Польське статистичне відомство.

В тій чи іншій мірі соціологічні дослідження проблематики прикордоння та транскордонного співробітництва проводилися також окремо країнами, які не так давно стали членами Свропейського Союзу і є сусідами України. Маються на увазі Угорщина, Словаччина, Румунія, Польща.

Що стосується України, то проблематика прикордоння і транскордонних процесів, звичайно ж, не могла і не може не цікавити наших соціологів. Ще в далекому 1988 році в Ужгородському державному університеті була створена одна із перших в Україні лабораторія соціологічних досліджень, в якій активно працювали, зокрема, відомі сьогодні українські соціологи: кандидат філософських наук, доцент Ужгородського національного університету О.В. 
Пелін та доктор соціологічних наук, провідний науковий співробітник Інституту соціології НАН України, директор Центру соціальних і політичних досліджень «Соціс» О.Г. Стегній. Лабораторії також всіляко допомагав нині доктор соціологічних наук, провідний науковий співробітник Інституту соціології АН України, Генеральний директор TNS Україна М.М. Чурилов. Лабораторією був отриманий певний матеріал щодо впливу транскордонних процесів на міжетнічні та міжконфесійні відносини в прикордонному регіоні.

На жаль, вкрай обмежені ресурси не дозволили в той час провести повноцінне дослідження з прикордонної тематики.

Друга, вже більш вдала спроба здійснити таке дослідження була зроблена в 2007 році. Тоді новостворений Інститут транскордонного співробітництва виступив ініціатором і замовником пілотного соціологічного дослідження «Новий Східний кордон Європейського Союзу: питання транспарентності, безпеки i транскордонного співробітництва (Польща, Словаччина, Угорщина, Україна)». Це дослідження було виконано під керівництвом кандидата соціологічних наук, доцента П.В. Токаря [4].

До його організації було залучено дослідницькі центри, урядові та неурядові структури, місцеві органи влади, фонди та громадські організації всього 10 представництв у чотирьох країнах - учасницях проекту (Польща, Словаччина, Угорщина, Україна).

Результати проведеного дослідження дають багату інформацію про актуальний стан транскордонного співробітництва між зазначеними державами, щодо порівняльного аналізу рівня його розвитку, оцінки роботи консульських та прикордонних служб. Проте, на жаль, і це дослідження було обмежено як часом, так і фінансовими можливостями.

Ті чи інші аспекти новітнього транскордонного співробітництва знайшли своє відображення в інших проведених українськими соціологами дослідженнях як на центральному, так і на регіональному рівнях, причому не тільки на Західному, але й на Східному кордонах України.

Значні можливості для здійснення масштабної і цілісної роботи із соціологічного відображення сучасних транскордонних процесів відкриває реалізація проекту «Кордони очима людей», що виконується Інститутом транскордонного співробітництва разом із партнерами за програмою ENPI Європейського Союзу в сегменті Угорщина-Словаччина-Румунія-Україна.

Загальна мета Проекту:

Формування соціологічного сервісу транскордонного співробітництва сусідніх регіонів Угорщини, Словаччини, Румунії та України.

\section{Специфічні цілі:}

1. Розробка методології та інструментарію соціологічного аналізу транскордонного співробітництва.

2. Створення Міжнародного центру соціологічного аналізу транскордонного співробітництва (МЦСА) як спеціального механізму міжнародного моніторингу транскордонних процесів, що забезпечить 
надійний «зворотний зв’язок» між органами управління транскордонного співробітництва та їх безпосередніми учасниками - населенням прикордонних регіонів Угорщини, Румунії, Словаччини та України.

3. Проведення стартового міжнародного соціологічного дослідження транскордонного співробітництва сусідніх регіонів Угорщини, Словаччини, Румунії та України.

4. Розроблення навчально-методичного пакету курсу «Соціологія транскордонних процесів» для впровадження у навчальний процес вищих навчальних закладів сусідніх регіонів Угорщини, Словаччини, Румунії та України.

Період реалізації Проекту:

06.2012 - 05.2014.

\section{Аплікант:}

Інститут транскордонного співробітництва, м. Ужгород, Україна

\section{Партнери:}

KIUT Асоціація регіонального розвитку, м. Загонь, Угорщина,

Закарпатський державний університет, м. Ужгород, Україна.

Конкретно-соціологічне відображення транскордонних процесів (зокрема транскордонного співробітництва) та практичне використання отриманої в результаті цього відображення конкретно-соціологічної інформації є частиною системи інформаційного сервісу транскордонних процесів (зокрема транскордонного співробітництва).

Система інформаційного сервісу (CIC) транскордонних процесів (зокрема транскордонного співробітництва) - це система, що забезпечує виконання функцій отримання (добування), введення чи збору, зберігання, пошуку, обробки, передачі та практичного використання інформації щодо генеалогії, актуального перебігу та прогнозованого розвитку сучасних транскордонних процесів (зокрема транскордонного співробітництва).

Система інформаційного сервісу має власну архітектуру, яку можна розглядати через призму різних критеріїв. 3 точки зору компонентного складу СIC $є$ сукупністю елементів (блоків) власне інформаційного, технічного, програмного і організаційного забезпечення, а також персоналу.

Розбудова системи інформаційного сервісу транскордонного співробітництва здійснюсться спільними зусиллями суб'єктів ТКС із різних краӥн.

Свій внесок у розбудову СІC за вісім років свого існування вносить також Інститут транскордонного співробітництва та його партнери. Перше, закладено методологічну та методичну основу для плідної інформаційно-аналітичної роботи. ІТС розроблена система індексації та моніторингу транскордонних процесів, зокрема транскордонного співробітництва [5], підготовлена методика їі практичного використання [6]. Виконана пілотна імплементація цієї системи через проведення індексних моніторингових досліджень транскордонного співробітництва сусідніх 
регіонів Угорщини, Словаччини, Румунії та України [7]. Відрадно, що розроблений ITC продукт відразу знайшов практичне використання в інших сегментах нового Східного кордону Свропейського Союзу. Одна 3 перших спроб практичного застосування методології індексації транскордонного співробітництва була зроблена в рамках проекту «Індекс ТКС інформування зацікавлених сторін». Цей проект реалізувався в 2010-2011 рр. під егідою Міністерства закордонних справ Норвегії [8]. Ще один практичний досвід використання методології індексації транскордонного співробітництва отримано в результаті реалізації польсько-російського проекту «Рахуймося із кордонами» в $2011-2012$ рр. [9].

В листопаді 2012 року, на третьому Європейському форумі 3 транскордонного співробітництва у Кишиневі (ITC, як відомо, $\epsilon$ співорганізатором форумів) були презентовані результати ще одного проекту «Транскордонне співробітництво на новому Східному кордоні - вивчення фінського та норвезького досвіду», виконаного за методологією порівняльного аналізу на замовлення Міністерства закордонних справ Фінляндії [10]. Інститут транскордонного співробітництва виконав порівняльний аналіз прикордоння України та Європейського Союзу.

Дуже важливим напрямом інформаційно-аналітичного блоку сервісу транскордонного співробітництва $\epsilon$ транскордонна статистика. ITC ініціював розроблення проблеми «Сучасні транскордонні процеси та їх статистичне відображення». Аналіз статистичного зрізу цієї проблеми очолюють відомі вчені і практики - професор Йозеф Оленський та професор, віце-президент Російської академії економічних наук, наш земляк із Закарпаття В. М. Симчера. Результати розробки будуть представлені на черговому Всесвітньому статистичному Форумі у серпні 2013 року у Гонконзі. Ця робота виконується в рамках проекту «Краще знання - краща співпраця» Вишеградського Фонду.

Що стосується блоку інформаиії про генеалогію об'єкта, то тут ITC працює у двох напрямах. Перший пов'язаний із підготовкою міжнародним авторським колективом «Нарисів новітньої історії транскордонного співробітництва в Карпатському регіоні», що будуть представлені на інтерактивному сайті в он-лайн режимі та в друкованому вигляді. Ця робота виконується ITC разом із партнерами в рамках проекту «Історія, що об’єднує».

Другий напрям - створення Міжнародного музею новітньої історії транскордонного співробітництва в Карпатському регіоні - теж в онлайнрежимі і в експозиційному варіанті, рішення щодо проектного фінансування якого прийнято нещодавно.

Створено організаційний механізм імплементації теоретичних розробок - Міжнародний інститут транскордонного аналізу та менеджменту (МITAM). Схвалено Стратегію розвитку Інституту та його Статут. 
Формується його інфраструктура. За рахунок проектного фінансування вирішені питання матеріально-технічного та програмного забезпечення МITAM.

Готується інформаційно-довідковий ресурс (ІДР), без якого неможлива ділова транскордонна комунікація суб'єктів. Підготовлений проект створення «Словника транскордонного співробітництва» на 8 мовах (англійській, українській, угорській, словацькій, чеській, польській, румунській, молдовській), а також «Глосарія термінів транскордонного співробітництва» на цих мовах.

Сформовано потужне міжрегіональне експертне співтовариство (більше 40 високопрофесійних фахівців із числа науковців, представників органів державної влади та місцевого самоврядування, активістів громадських організацій із різних країн).

Таким чином, є підстави стверджувати, щяо система інформаційного сервісу транскордонного співробітництва поступово формується.

Підсумовуючи зазначене, можна, вочевидь, зробити такі основні висновки.

1. Блок конкретно-соціологічної інформації повинен стати невід'ємною складовою частиною системи інформаційного сервісу транскордонного співробітництва, бо без встановлення надійного та систематичного «зворотного зв'язку» між суб'єктами управління та населенням ефективна співпраця сусідніх регіонів неможлива.

2. У цій системі конкретно-соціологічний компонент повинен виконувати дві основні функції:

а) функцію генерування адекватної, всебічної та повної інформації про потреби й інтереси людей, які вони виражають в своїх оцінках процесів, що відбуваються на кордоні та довкола нього;

б) функцію коригування управління, яка полягає в максимально повному врахуванні цих оцінок при підготовці та прийнятті відповідних управлінських, найперше політичних рішень.

Поки що конкретно-соціологічне забезпечення є «ахіллесовою п'ятою» системи інформаційного сервісу транскордонного співробітництва. Спільна робота 3 реалізації проекту «Кордони очима людей» сприяла тому, щоб конкретно-соціологічне знання, як і належить, стало важливим елементом теорії і практики сучасних транскордонних процесів в Свропі.

\section{СПИСОК ВИКОРИСТАНИХ ДЖЕРЕЛ}

1. Eurobarometr [Електронний pecyрс] - Режим доступу: http://ec.europa.eu/public_opinion/index_en.htm

2. TNS [Електронний ресурс] - Режим доступу: http://www.tnsglobal.com/

3. Eurostat [Електронний pecypc] - Режим доступу: http://epp.eurostat.ec.europa.eu/portal/page/portal/eurostat/home/ 
4. Токар П. Нові реалії сучасних кордонів/ Токар П. - Ужгород: КП «Ужгородська міська друкарня», 2008. - 317 с.

5. Оптимізація системи транскордонного співробітництва: концепція та іiі пілотна імплементація (на прикладі сусідніх регіонів Угорщини, Словаччини, Румунії та України) / під ред. С.І. Устича. - Ужгород: Ліра, 2012. $-119 \mathrm{c}$.

6. Посібник із індексації та моніторингу транскордонного співробітництва / під ред. С.І. Устича. - Ужгород: Ліра, 2012. - 79 с.

7. Індексні дослідження транскордонного співробітництва / Ужгород: Ліра, 2012. - $244 \mathrm{c.}$

8. Index of TBC [Електронний ресурс] - Режим доступу: . http://www.borderdialogues.eu/index

9. Projekt „Liczmy się z granicą [Електронний pecypc] - Режим доступу: http://www.eurobalt.org.pl/index.php?option=com_content\&view=category\&layou $\mathrm{t}=$ blog\&id $=46 \&$ Itemid $=92$

10. Ex borea lux? Learning from the Finnish and Norwegian Experience of Cross-border Cooperation with Eastern Neighbours/ - Prague: ISD, 2012. - 96 P.

\section{REFERENCES}

1. Eurobarometr. Retrieved from: http://ec.europa.eu/public_opinion /index_en.htm

2. TNS. Retrieved from: http://www.tnsglobal.com/

3. Eurostat. Retrieved from: http://epp.eurostat.ec.europa.eu/portal/page/ portal/eurostat/home/

4. Tokar P. (2008). Novi realiyi suchasnykh kordoniv [New realities of modern frontiers]. Uzhhorod: KP «Uzhhorods'ka mis'ka drukarnya».

5. 1. Ustych, S.I. (Eds.). (2012). Optymizatsiya systemy transkordonnoho spivrobitnytstva: kontseptsiya ta yiyi pilotna implementatsiya [Optimization of the system of cross-border cooperation: the concept and its pilot implementation].Uzhhorod: Instytut transkordonnoho spivrobitnytstva.

6. 1. Ustych, S.I. (2012). Posibnyk $\mathrm{z}$ indeksatsiyi ta monitorynhu transkordonnoho spivrobitnytstva [Textbook to indexing and monitoring of crossborder cooperation].Uzhhorod: Instytut transkordonnoho spivrobitnytstva.

7. Indeksni doslidzhennya transkordonnoho spivrobitnytstva (2012) [Crossborder cooperation indexes]. Uzhhorod: Lira.

8. Index of TBC Retrieved from: http://www.borderdialogues.eu/index

9. Projekt „Liczmy się $\mathrm{z}$ granicą [The project "Let's face the border]. Retrieved from: http://www.eurobalt.org.pl/index.php? option=com content $\&$ view $=$ category $\&$ layout $=$ blog $\& i d=46 \&$ Itemid $=92$

10. Ex borea lux? Learning from the Finnish and Norwegian Experience of Cross-border Cooperation with Eastern Neighbours (2012).Prague: ISD. 